\title{
良導絡に与える温泉の影響について
}

Ryodoraku after bathing in hot spring water

高橋 伸彦 ${ }^{1)}$ 神 正照 ${ }^{2)}$

\section{【要 約】}

温泉が良導絡に与える影響について調べた。 9名の男女ボランテアを硫化水素泉、炭酸 水素塩泉及び水道水浴を行う 3 群に分け、朝 6 時より 16 時まで 2 時間毎に入浴と食事を繰 り返しながら良導絡、体インピーダンス (IMP)、皮虐湿度、尿の酸化還元電位 (ORP) を各 6 回、及び好中球リンパ球比を 6 時、 12 時、16 時の 3 回測定した。

その結果良導絡は概して朝低く、夕方にかけ て高くなる傾向が認められた。IMPと皮虐湿度 は良導絡とは無関係であった。硫黄泉浴後ORP は低下し、良導絡は増加することが多かった。 反対に水道水浴後尿のORPは增加し、良導絡は 減少することが多かった。

また炭酸水素塩泉ではそれらの中間的な変動 を示した。

好中球リンパ球比は6時と 12 時及び16時の 值との間に有意差があったが、浴水による差 は有意ではなかった。

好中球リンパ球比からみて良導絡が朝低 く、午後高くなる傾向は交感神経緊張と関係 すると考えられた。良導絡が体インピーダン スや皮虐湿度と関係がなかったことは、良導 絡が表皮における現象であることを示すもの と思われた。

更に浴水の違いで良導絡が変動し、それが 体液のORPと関連があると思われたので、体 液の電気的な性質も良導絡に影響を与えるも のと思われた。

\section{【緒 言】}

温泉入浴が体に良いと喧伝されている。しか しそれが良導絡にどんな影響を与えるかについ ては良く知られていない。そこで温泉入浴が良 導絡に与える影響について、尿の酸化還元電位 (ORP)、体インピーダンス(IMP)、皮虐湿度及 び好中球リンハ球比などの面から調べた。

\section{【方 法】}

入浴試験にはORPの大きく異なる水道水、炭 酸水素塩泉、硫黄泉の 3 種類の浴水を用いた。

対象者は年龄 22-26歳、健康な男女の大学 生 (男 3 名, 女 6 名) 各浴水 3 名づつの計 9 名 である。

各自からインフォームドコンセントを得た 後、午前 6 時より 16 時まで 2 時間おきに入浴 と食事を交互に繰り返しながら良導絡、タ二 夕製体脂肪率計の $50 \mathrm{MHz}$ 電流による体イン ピーダンス(IMP)、スカラ社製モイスチャー チェッカーMY707S（皮膚湿度計）による手 の良導絡測定点の皮庙湿度、更に尿のORPを 夫々 6 回測定し、ORPの値は標準水素電極電 位に換算して用いた。また 6 時、12時及び 16 時に血球計算を計 3 回行い、好中球リンハ球 比を計算した。その統計処理にはD Dr.SPSS 8.0J for Windows の一元配置分散分析を用い た。入浴は 5 分間頸まで浸漬し、湯温は 42 度 で試験を行った。また気圧、気温及び湿度を 当院に設置したウエーザーモニターII（俶 エーオーアール製）によって測定した。

\footnotetext{
1）鳴子医院 $\overline{7} 989-6823$ 宮城県玉造郡鳴子町字湯元 27-3 Tel. 0229-83-3019 Fax. 0229-82-2024 E-mail:nobuhiko@f8.dion.ne.jp

2）東北工業大学 情報処理技術研究所 助教授 † 982-8577 仙台市太白区八木山香澄町 35-1 Tel. 022-229-1151 Fax. 022-229-0005 Associate Professor, Informatics Laboratory, Tohoku Institute of Technology キーワード：良筧絡、温泉、酸化通元西位
} 
【結 果】

上記の測定結果を表 1 、及び表 2 にとめて
示す。また測定値とその直前の測定値との差 を表 3 及び表 4 に示す。

\section{表 1-1 良翼絡䁌定結果}

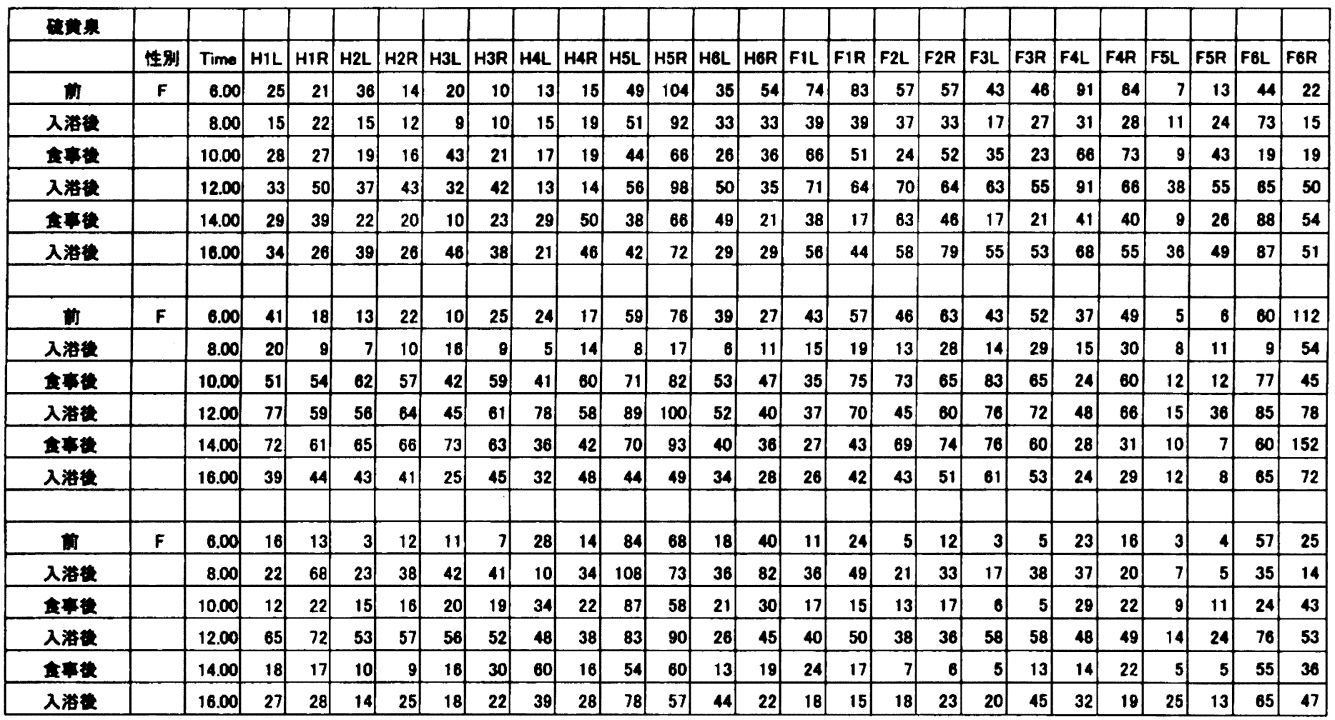

\section{表 1一2 良玍絡涀定結果}






\section{表 1-3 良政絡測定結果}

\begin{tabular}{|c|c|c|c|c|c|c|c|c|c|c|c|c|c|c|c|c|c|c|c|c|c|c|c|c|c|c|}
\hline 水进水 & & & & & & & & & & & & & & & & & & & & & & & & & & \\
\hline & 珄䟝 & Time & HIL & H1R & H2L & H2R & H3L & IJR & HAL & HAR & H5L & H5R & $\mathrm{H} 6 \mathrm{~L}$ & H6R & FIL & F1R & F2L & F2R & F3L & F3R & FAL & F 4R & F5L & $=5 R$ & $\mathrm{~F} 6 \mathrm{~L}$ & $=6 R$ \\
\hline 首 & $M$ & 6.00 & 40 & 33 & 36 & 25 & 21 & 23 & 36 & 22 & 52 & 42 & 51 & 35 & 43 & 39 & 34 & 32 & 26 & 31 & 40 & 29 & 22 & 12 & 17 & 10 \\
\hline 金事缕 & & 10.00 & 62 & 60 & 44 & 39 & 31 & 39 & 30 & 16 & 47 & 52 & 24 & 37 & 56 & 84 & 54 & 60 & 67 & 60 & 74 & 64 & 40 & 20 & 24 & 40 \\
\hline 入港缕 & & 12.00 & 68 & 68 & 19 & 25 & 62 & 35 & 57 & 9 & 14 & 74 & 59 & 57 & 34 & 48 & 41 & 33 & 59 & 54 & 55 & 68 & 48 & 45 & 52 & 73 \\
\hline 金事缕 & & 14.00 & 84 & 62 & 38 & 30 & 50 & 76 & 85 & 73 & 55 & 65 & 93 & 91 & 42 & 81 & 50 & 54 & 76 & 72 & 48 & 70 & 59 & 47 & 100 & 101 \\
\hline 剖 & $M$ & 6.00 & 26 & 16 & 14 & 8 & 7 & 10 & 13 & 14 & 47 & 66 & 9 & 13 & 23 & 37 & 31 & 35 & 31 & 35 & 32 & 24 & 23 & 14 & 46 & 4 \\
\hline 入淃嗖 & & 8.00 & 31 & 27 & 14 & 12 & 12 & 30 & 23 & 17 & 50 & 77 & 22 & 23 & 40 & 54 & 46 & 61 & 22 & 52 & 40 & 41 & 21 & 23 & 39 & 36 \\
\hline 金事绻 & & 10.00 & 58 & 40 & 27 & 15 & 21 & 24 & 18 & 20 & 31 & 111 & 34 & 53 & 36 & 19 & 51 & 61 & 43 & 67 & 53 & 25 & 56 & 25 & 34 & 37 \\
\hline 入汶缕 & & 12.00 & 20 & 25 & 17 & 5 & 9 & 14 & 18 & 19 & 51 & 108 & 23 & 54 & 32 & 40 & 33 & 41 & 39 & 36 & 34 & 28 & 25 & 14 & 58 & 16 \\
\hline 首 & $M$ & 6.00 & 47 & 51 & 29 & 71 & 27 & 99 & 50 & 34 & 82 & 63 & 31 & 38 & 34 & 39 & 44 & 48 & 39 & 37 & 30 & 35 & 59 & 72 & 77 & 57 \\
\hline 入港䜾 & & 8.00 & 57 & 86 & 40 & 119 & 21 & 118 & 36 & 49 & 76 & 88 & 47 & 65 & 46 & 50 & 57 & 54 & 66 & 47 & 52 & 55 & 83 & 95 & 74 & 78 \\
\hline 金事数 & & 10.00 & 69 & 58 & 32 & 130 & 33 & 51 & 42 & 35 & 89 & 97 & 41 & 59 & 40 & 45 & 50 & 43 & 51 & 70 & 41 & 65 & 40 & 104 & 83 & 80 \\
\hline 入湭缕 & & 12.00 & 45 & 56 & 29 & 106 & 33 & 31 & 43 & 31 & 42 & 100 & 53 & 45 & 27 & 28 & 22 & 21 & 38 & 25 & 30 & 49 & 37 & 24 & 63 & 56 \\
\hline  & & 14.00 & 67 & $\infty 0$ & 45 & 118 & 56 & 84 & 96 & 51 & 118 & 128 & 73 & 104 & 35 & 64 & 56 & 53 & 50 & 57 & 42 & 61 & 43 & 76 & 71 & 75 \\
\hline 入㳣漛 & & 16.00 & 64 & 82 & 43 & 129 & 47 & 93 & 74 & 85 & 75 & 92 & 69 & 51 & 35 & 54 & 34 & 39 & 33 & 37 & 32 & 47 & 48 & 93 & 83 & 74 \\
\hline
\end{tabular}

\section{表 2-1 体インピーダンス、皮夙湿度、尿の酸化逐元重位および好中球リンパ球比}



\footnotetext{
住 IMP:体インピーダンス ORP:化园元而位 NLR:好中球リンハ球比 N:好中球 L:リンハ球
} 
表 2-2 体インピーダンス、皮成湿度、尿の酸化通元西位および好中球リンパ球比

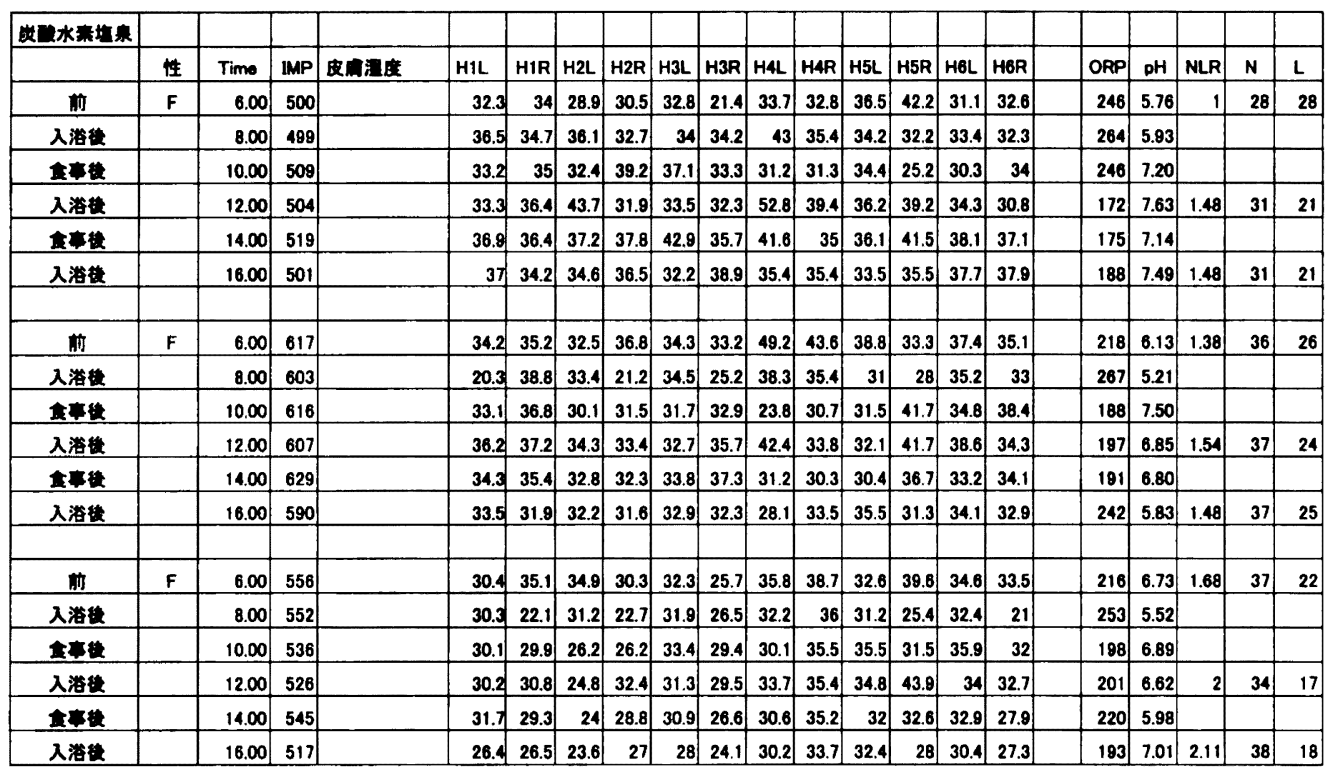

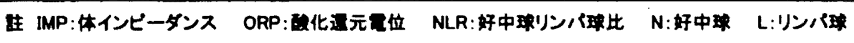

\section{表 2-3 体インピーダンス、皮间湿度、尿の酸化通元玉位および好中球リンパ球比}

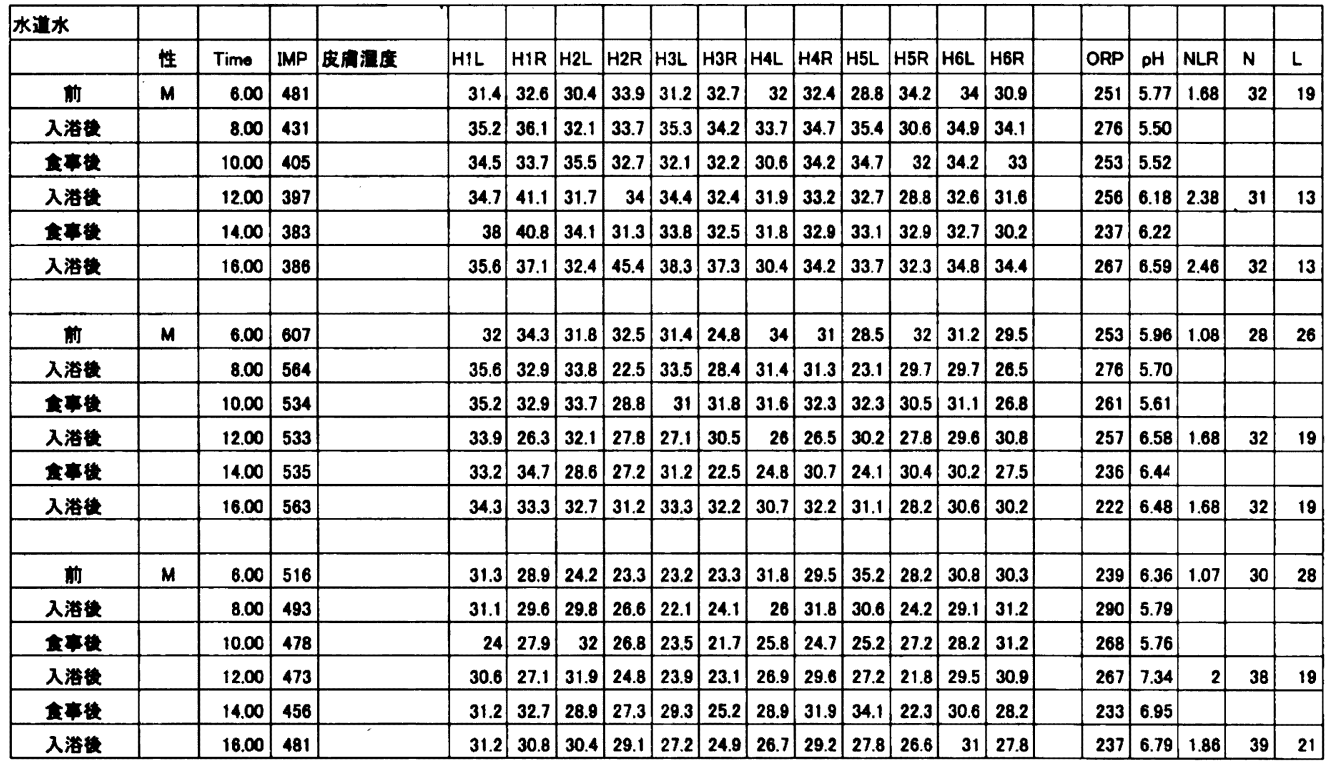




\section{表 3-1 良等絡洎定值の直前值との差}



\section{表 3-2 良導絡溳定値の直前値との差}

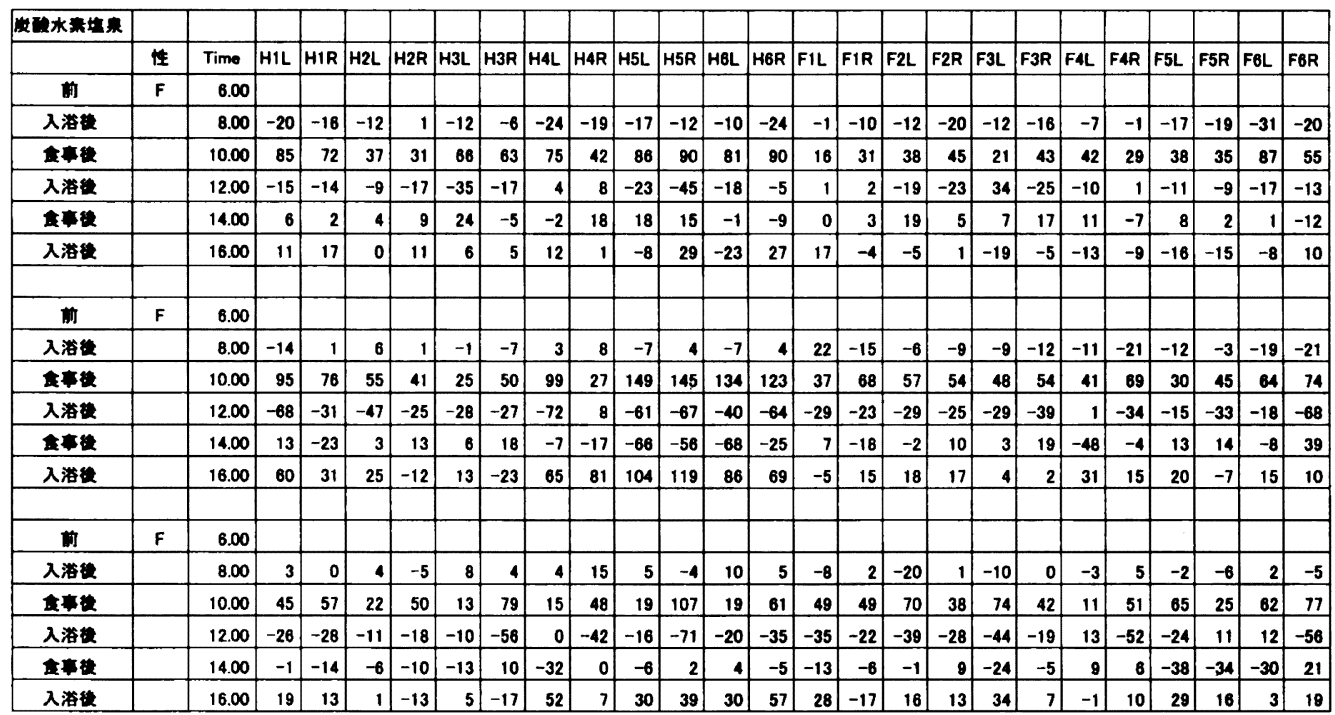




\section{表 3-3 良導絡貺定佰の直前值との差}

\begin{tabular}{|c|c|c|c|c|c|c|c|c|c|c|c|c|c|c|c|c|c|c|c|c|c|c|c|c|c|c|}
\hline 水滥水 & & & & & & & & & & & & & & & & & & & & & & & & & & \\
\hline & 性 & \begin{tabular}{l|l} 
Time & $H$
\end{tabular} & \begin{tabular}{l|l} 
HIL \\
\end{tabular} & HIR & $\mathrm{H} 2 \mathrm{~L}$ & H2R & H3L & H3R & HAL & H4R & H5L & \begin{tabular}{|l|l|} 
H5R \\
\end{tabular} & $\mathrm{H} 6 \mathrm{~L}$ & \begin{tabular}{|l|} 
H6R \\
\end{tabular} & F1L & F1R & F2L & F2R & F3L & F3R & FAL & F4R & F5L & F5R & $F 6 \mathrm{~L}$ & F6R \\
\hline 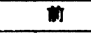 & $M$ & 6.00 & & & & & & & & & & & & & & & & & & & & & & & & \\
\hline 入清级 & & 8.00 & 39 & 46 & 19 & 24 & 31 & 51 & 40 & 56 & 22 & 17 & 31 & 25 & 31 & 33 & 34 & 41 & 61 & 43 & 27 & 34 & 46 & 62 & 61 & 56 \\
\hline 金禹缕 & & 10.00 & \begin{tabular}{|c|}
-17 \\
\end{tabular} & -19 & -11 & \begin{tabular}{|l|}
-10 \\
\end{tabular} & -21 & -35 & -46 & -62 & -27 & -7 & \begin{tabular}{|l|}
-58 \\
\end{tabular} & -23 & \begin{tabular}{|l|}
-18 \\
\end{tabular} & 12 & -14 & \begin{tabular}{|l|}
-13 \\
\end{tabular} & -20 & -14 & 7 & 1 & \begin{tabular}{|l|} 
\\
\end{tabular} & \begin{tabular}{|l|}
-54 \\
\end{tabular} & -54 & -26 \\
\hline 入彗 & & 12.00 & 6 & 6 & -25 & \begin{tabular}{|l|}
-14 \\
\end{tabular} & 31 & -4 & 27 & -7 & \begin{tabular}{|l|}
-33 \\
\end{tabular} & 22 & 35 & 20 & \begin{tabular}{|l|}
-22 \\
\end{tabular} & -36 & -13 & -27 & -8 & -6 & \begin{tabular}{|l|}
-19 \\
\end{tabular} & 4 & 6 & 25 & 28 & 33 \\
\hline 金事缕 & & 14.00 & 26 & -4 & 19 & 5 & -12 & 41 & 28 & 64 & 41 & -9 & 34 & 34 & 8 & 33 & 9 & 21 & 17 & 18 & -7 & 2 & 13 & 2 & 48 & 28 \\
\hline 入澄统 & & 16.00 & -37 & -14 & 2 & 1 & -6 & -42 & -12 & -22 & \begin{tabular}{|l|}
-38 \\
\end{tabular} & -25 & \begin{tabular}{|l|}
-43 \\
\end{tabular} & \begin{tabular}{|l|}
-59 \\
\end{tabular} & 1 & -33 & -13 & \begin{tabular}{|l|}
-16 \\
\end{tabular} & \begin{tabular}{|l|}
-18 \\
\end{tabular} & \begin{tabular}{|l|}
-23 \\
\end{tabular} & 6 & 1 & -9 & 5 & -34 & -16 \\
\hline & & & & & & & & & & & & & & & & & & & & & & & & & & \\
\hline 前 & $m$ & 6.00 & & & & & & & & & & & & & & & & & & & & & & & & \\
\hline 入㳻统 & & 8.00 & 5 & 11 & 0 & 4 & 5 & 20 & 10 & 3 & 3 & 11 & 13 & 10 & 17 & 17 & 15 & 26 & -9 & 17 & 8 & 17 & -2 & 9 & -7 & 32 \\
\hline 소눈 & & 10.00 & 27 & 13 & 13 & 3 & 9 & -6 & -5 & 3 & \begin{tabular}{|l|}
-19 \\
\end{tabular} & 34 & 12 & 30 & -4 & -35 & 5 & 0 & 21 & 15 & 13 & \begin{tabular}{|l|}
-16 \\
\end{tabular} & 35 & 2 & -5 & 1 \\
\hline 入港统 & & 12.00 & -38 & -15 & -10 & -10 & -12 & -10 & 0 & -1 & 20 & -3 & \begin{tabular}{|l|}
-11 \\
\end{tabular} & 1 & -4 & 21 & -18 & -20 & -4 & -31 & \begin{tabular}{|l|}
-19 \\
\end{tabular} & 3 & -31 & \begin{tabular}{|l|}
-11 \\
\end{tabular} & 24 & -21 \\
\hline 去事妓 & & 14.00 & 27 & 43 & 14 & 18 & 4 & -2 & 8 & 8 & 31 & 22 & 48 & -7 & \begin{tabular}{|l|}
-15 \\
\end{tabular} & 4 & 9 & 11 & 6 & 0 & 12 & 18 & 9 & 9 & 11 & 23 \\
\hline 入垱掕 & & 16.00 & -25 & -50 & -12 & -12 & 0 & 2 & -8 & -10 & \begin{tabular}{|l|}
-27 \\
\end{tabular} & -37 & -34 & -16 & 11 & -1 & 0 & -5 & \begin{tabular}{|l|}
-18 \\
\end{tabular} & 6 & 18 & -6 & 7 & 6 & -1 & 4 \\
\hline & & & & & & & & & & & & & & & & & & & & & & & & & & \\
\hline 摬 & $M$ & 6.00 & & & & & & & & & & & & & & & & & & & & & & & & \\
\hline 入溚统 & & 8.00 & 10 & 35 & 11 & 48 & -6 & 19 & -14 & 15 & -6 & 25 & 16 & 27 & 12 & 11 & 13 & 6 & 27 & 10 & 18 & 20 & 24 & 23 & -3 & 21 \\
\hline 金证统 & & 10.00 & 12 & -27 & -8 & 20 & 12 & -67 & \begin{tabular}{l|l}
6 & \\
\end{tabular} & \begin{tabular}{|l|}
-14 \\
\end{tabular} & 13 & 9 & -6 & -6 & \begin{tabular}{l|}
-6 \\
\end{tabular} & -5 & -7 & -11 & \begin{tabular}{|l|}
-15 \\
\end{tabular} & 23 & \begin{tabular}{|l|}
-11 \\
\end{tabular} & 10 & -43 & 9 & 9 & 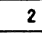 \\
\hline 入港㧼 & & 12.00 & -24 & -3 & -3 & -33 & 0 & -20 & 1 & -4 & \begin{tabular}{|l|}
-47 \\
\end{tabular} & 3 & 12 & -14 & \begin{tabular}{|l|}
-13 \\
\end{tabular} & -17 & -28 & -22 & -13 & \begin{tabular}{|l|} 
\\
\end{tabular} & -11 & \begin{tabular}{|l|}
-16 \\
\end{tabular} & -3 & -80 & -20 & -24 \\
\hline 소운 & & 14.00 & 22 & 34 & 16 & 12 & 23 & 53 & 53 & 20 & 76 & 28 & 20 & \begin{tabular}{l|l}
59 \\
\end{tabular} & 8 & 36 & 34 & 32 & 12 & 32 & 12 & 12 & 6 & 52 & 8 & 19 \\
\hline 入渚漛 & & 16.00 & -3 & -8 & -2 & 11 & -9 & 9 & -22 & 34 & $-43 \mid$ & -36 & -4 & $|-53|$ & 0 & -10 & -22 & -14 & \begin{tabular}{|l|}
-17 \\
\end{tabular} & -20 & \begin{tabular}{|l|}
-10 \\
\end{tabular} & -14 & 5 & 17 & 12 & -1 \\
\hline
\end{tabular}

\section{表 4-1 体インピーダンス、皮湿度、尿の酸化通元要位および好中球リンパ球比の直前値との差}

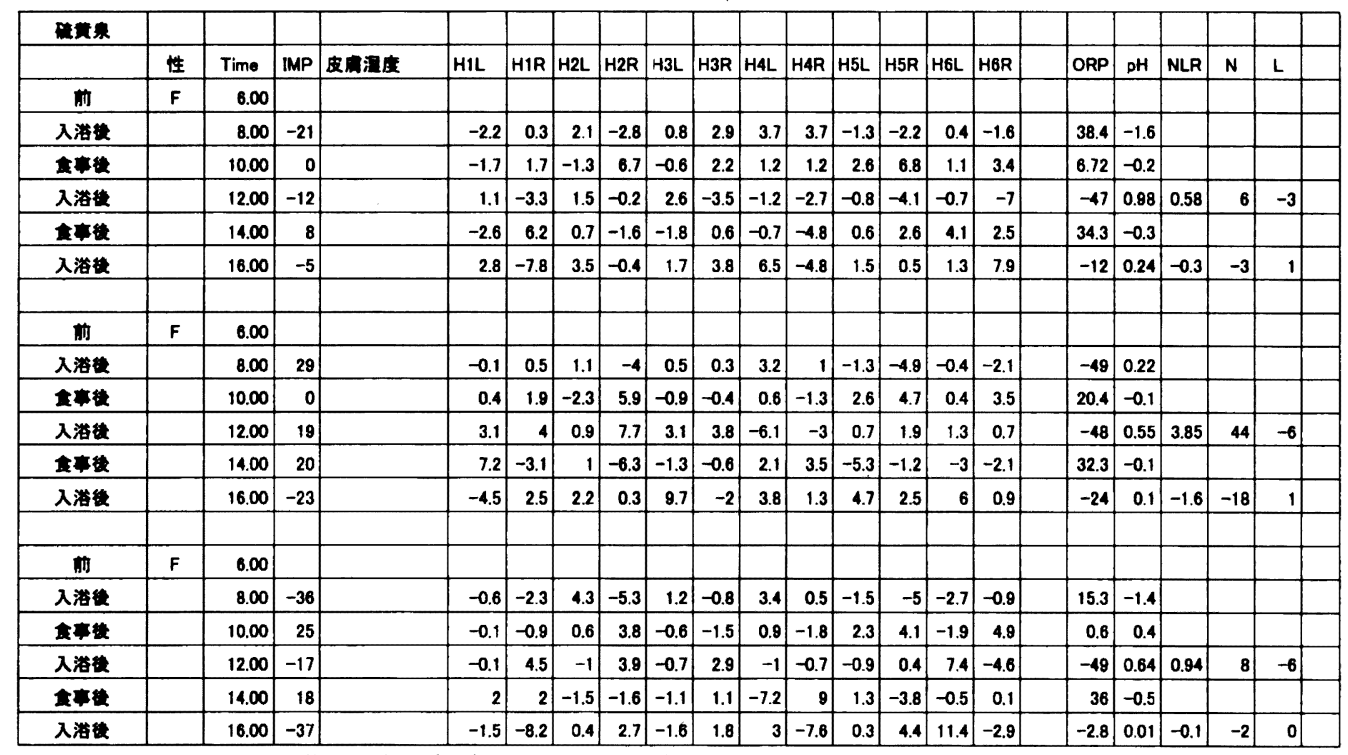

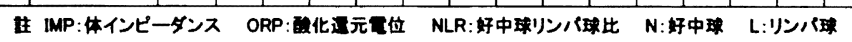


表 4-2 体インピーダンス、皮间湿度、尿の酸化通元電位および好中球リンパ球比の直前值との差

\begin{tabular}{|c|c|c|c|c|c|c|c|c|c|c|c|c|c|c|c|c|c|c|c|c|c|}
\hline \multirow[t]{2}{*}{ 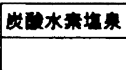 } & & & & & & & & & & & & & & & & & & & & & \\
\hline & 性 & Time & IMP & 皮用濯度 & HIL & \begin{tabular}{|l|r}
$H 1 R$ & \\
\end{tabular} & H2L & H2R & \begin{tabular}{|l|l} 
HIL & 1 \\
\end{tabular} & \begin{tabular}{|l|l} 
H3R & $H$ \\
\end{tabular} & HAL & HAR & H5L & H5R & H6L & H6R & ORP & \begin{tabular}{|l|l} 
pH & 1 \\
\end{tabular} & NLR & $\mathrm{N}$ & L \\
\hline 而 & $F$ & 0.00 & & & & & & & & & & & & & & & & & & & \\
\hline 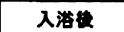 & & 8.00 & -1 & & 4.2 & $\begin{array}{ll}0.7 \\
\end{array}$ & 7.2 & \begin{tabular}{|l|}
2.2 \\
\end{tabular} & \begin{tabular}{|l|}
1.2 \\
\end{tabular} & \begin{tabular}{|l|}
12.8 \\
\end{tabular} & $\begin{array}{ll}9.3 \\
\end{array}$ & 2.6 & -2.3 & $\mid-10$ & 2.3 & \begin{tabular}{|l|} 
\\
\end{tabular} & \begin{tabular}{|l|}
18.6 \\
\end{tabular} & \begin{tabular}{|l|} 
\\
\end{tabular} & & & \\
\hline  & & 10.00 & 10 & & -3.3 & \begin{tabular}{|l|}
0.3 \\
\end{tabular} & -3.7 & 6.5 & 3.1 & -0.9 & -12 & -4.1 & 0.2 & -7 & -3.1 & 1.7 & -18 & 1.27 & & & \\
\hline 入海德 & & 12.00 & -5 & & 0.1 & 1.4 & 11.3 & \begin{tabular}{|l|l|} 
& -7.3 \\
\end{tabular} & $\mid-3.6$ & -1 & 21.6 & 8.1 & 1.8 & 14 & 4 & \begin{tabular}{|l|} 
\\
\end{tabular} & -74 & \begin{tabular}{|l|} 
\\
\end{tabular} & 0.48 & 3 & -7 \\
\hline 金事缕 & & 14.00 & 15 & & 3.6 & 0 & -6.5 & 5.9 & \begin{tabular}{|l|}
9.4 \\
\end{tabular} & 3.4 & -11 & -4.4 & -0.1 & 2.3 & 3.8 & 6.3 & 2.88 & -0.5 & & & \\
\hline 入漠 & & 16.00 & -18 & & 0.1 & -2.2 & -2.6 & $\mid-1.3$ & $\mid-11$ & 3.2 & -6.2 & 0.4 & -2.6 & -6 & -0.4 & \begin{tabular}{|l|}
0.8 \\
\end{tabular} & 13.3 & 0.35 & 0 & 0 & 0 \\
\hline & & & & & & & & & & & & & & & & & & & & & \\
\hline 而 & $F$ & 6.00 & & & & & & & & & & & & & & & & & & & \\
\hline 入垱缕 & & 8.00 & -14 & & -13.9 & 3.6 & 0.9 & -16 & \begin{tabular}{|l|}
0.2 \\
\end{tabular} & -8 & -11 & -8.2 & -7.8 & -5.3 & -2.2 & -2.1 & 48.6 & \begin{tabular}{|l|}
-0.9 \\
\end{tabular} & & & \\
\hline 金事绻 & & 10.00 & 13 & & 12.8 & -2 & -3.3 & 10.3 & -2.8 & 7.7 & -15 & -4.7 & 0.5 & 13.7 & -0.4 & 5.4 & -79 & 2.29 & & & \\
\hline 入沿嵝 & & 12.00 & -9 & & 3.1 & \begin{tabular}{|l|}
0.4 \\
\end{tabular} & 4.2 & 1.9 & 1 & 2.8 & 18.6 & 3.1 & 0.6 & 0 & 3.8 & -4.1 & 9.28 & -0.7 & 0.16 & 1 & -2 \\
\hline 金事缕 & & 14.00 & 22 & & -1.9 & \begin{tabular}{|l|}
-1.8 \\
\end{tabular} & -1.5 & -1.1 & \begin{tabular}{|l|}
1.1 \\
\end{tabular} & 1.6 & -11 & -3.5 & -1.7 & -5 & -5.4 & \begin{tabular}{|l|}
-0.2 \\
\end{tabular} & \begin{tabular}{|l|}
-6.6 \\
\end{tabular} & -0.0 & & & \\
\hline 入澄业 & & 16.00 & -39 & & -0.8 & -3.5 & -0.6 & $|-0.7|$ & -0.9 & -5 & -3.1 & \begin{tabular}{|r|}
3.2 \\
\end{tabular} & 5.1 & $|-5.4|$ & 0.9 & \begin{tabular}{|r|} 
\\
\end{tabular} & 50.9 & -1 & -0.1 & 0 & 1 \\
\hline & & & & & & & & & & & & & & & & & & & & & \\
\hline 而 & $\mathbf{F}$ & 0.00 & & & & & & & & & & & & & & & & & & & \\
\hline 入浯啳 & & 8.00 & -4 & & -0.1 & \begin{tabular}{|c|}
-13 \\
\end{tabular} & -3.7 & $\mid-7.6$ & -0.4 & 0.8 & -3.6 & $\mid-2.7$ & \begin{tabular}{|l|}
-1.4 \\
\end{tabular} & $\mid-14$ & -2.2 & \begin{tabular}{|l|}
-13 \\
\end{tabular} & \begin{tabular}{|l|}
37.3 \\
\end{tabular} & $\mid-1.2$ & & & \\
\hline 金事缕 & & 10.00 & -16 & & -0.2 & \begin{tabular}{|l|}
7.8 \\
\end{tabular} & -5 & 3.5 & \begin{tabular}{|l|}
1.5 \\
\end{tabular} & 2.9 . & \begin{tabular}{|l|}
-2.1 \\
\end{tabular} & -0.5 & 4.3 & 6.1 & 3.5 & 11 & -55 & \begin{tabular}{|l|}
1.37 \\
\end{tabular} & & & \\
\hline 入滏潾 & & 12.00 & -10 & & 0.1 & 0.9 & \begin{tabular}{|l|}
-1.4 \\
\end{tabular} & 6.2 & -2.1 & 0.1 & 3.6 & -0.1 & -0.7 & 12.4 & -1.9 & 0.7 & \begin{tabular}{|l|}
3.56 \\
\end{tabular} & -0.3 & \begin{tabular}{|l|}
0.32 \\
\end{tabular} & -3 & -5 \\
\hline 金种绕 & & 14.00 & 19 & & 1.5 & \begin{tabular}{|l|}
-1.5 \\
\end{tabular} & -0.8 & -3.6 & -0.4 & \begin{tabular}{|l|}
-2.9 \\
\end{tabular} & -3.1 & -0.2 & \begin{tabular}{|l|} 
\\
\end{tabular} & -11 & \begin{tabular}{|l|} 
\\
\end{tabular} & \begin{tabular}{|l|}
-4.8 \\
\end{tabular} & 19.2 & \begin{tabular}{|l|}
-0.6 \\
\end{tabular} & & & \\
\hline 入港㧼 & & 16.00 & -28 & & -5.3 & $|-2.8|$ & -0.4 & $\mid-1.8$ & -2.9 & $|-2.5|$ & -0.4 & $|-1.5|$ & \begin{tabular}{|l|} 
\\
\end{tabular} & -4.6 & -2.5 & -0.6 & -27 & 1.03 & 0.11 & 4 & 1 \\
\hline
\end{tabular}

\section{表 4-3 体インピーダンス、皮俨湿度、尿の酸化通元雪位および好中球りンパ球比の直前値との差}

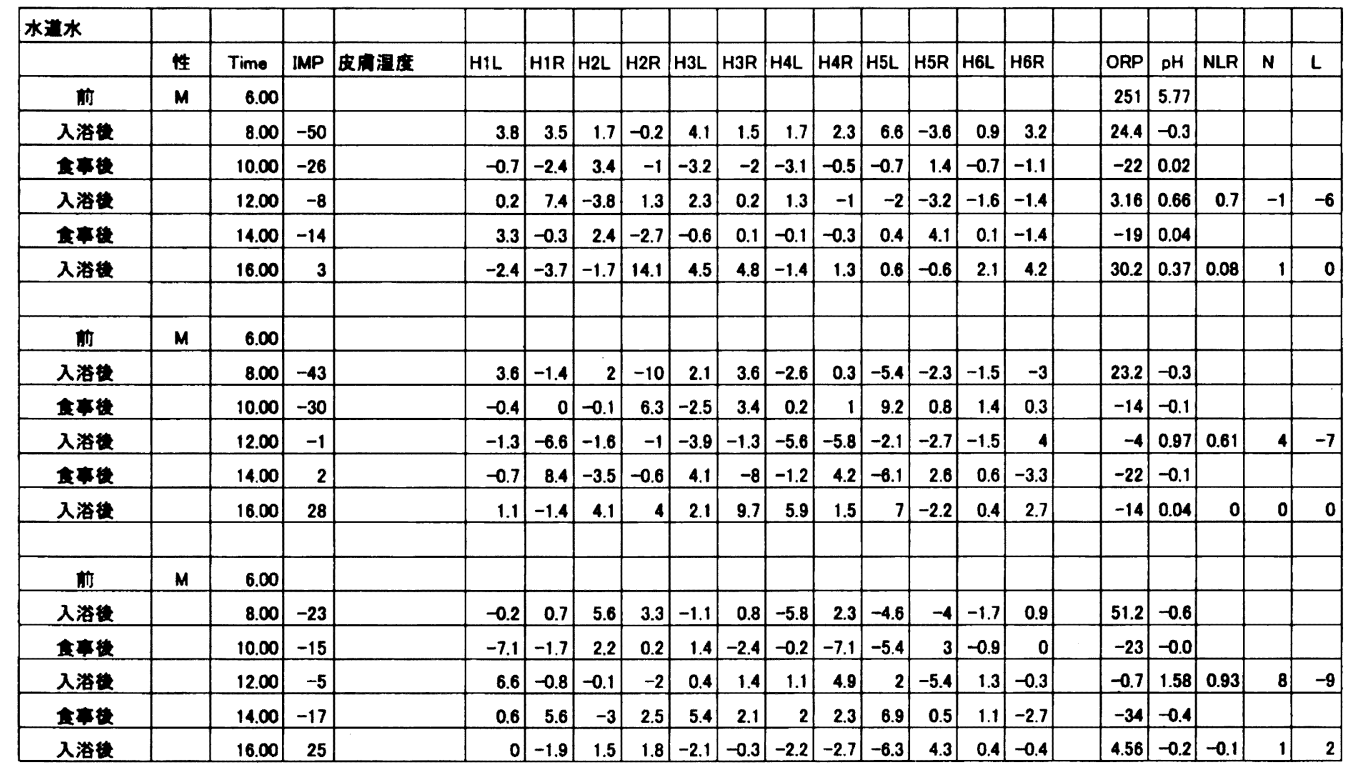


良導絡の 1 日 6 回の測定結果を測定順序毎 示も同様に累積図表として示す。 の累積図表として、また同じ結果の時系列表

Fig. 1ー1ー1 良鼻絡チャート

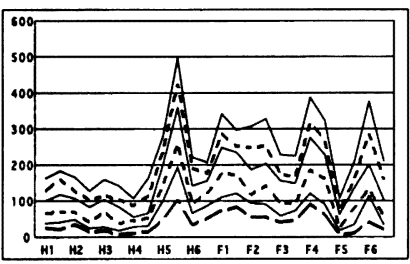

Fig. 1-1-2 良導絡チャート

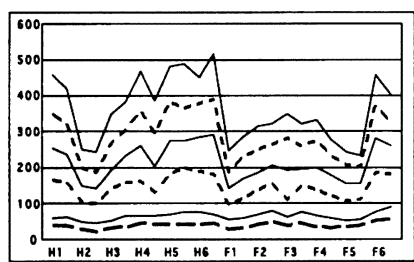

Fig. 1-1-3 良導絡チャート

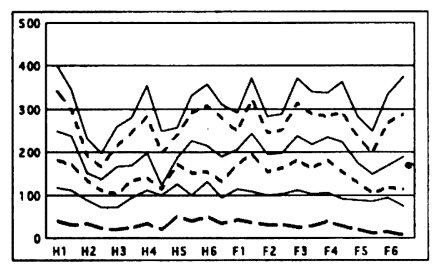

\section{累积図表 硫黄息 固人別}



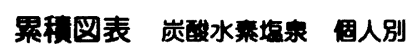

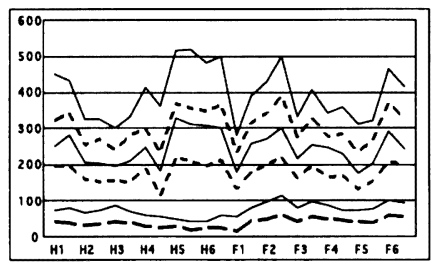

\section{累程図表 水道水 個人別}






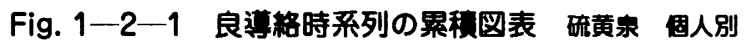



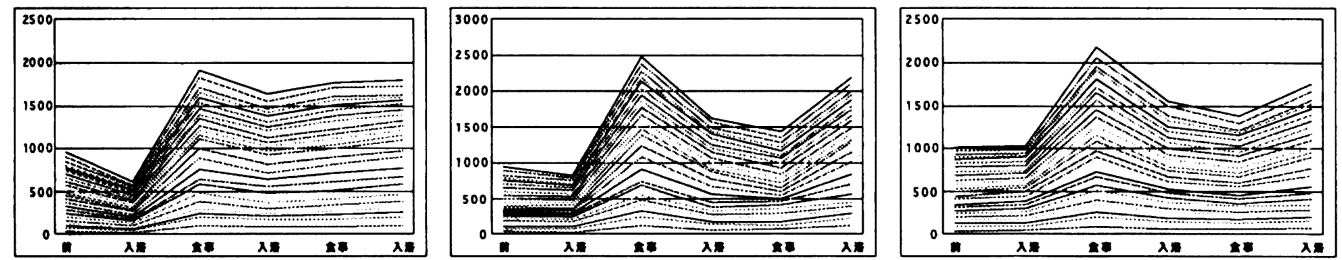

Fig. 1-2-3 良導䊀時系列の累䅡图表 水道水 固人別
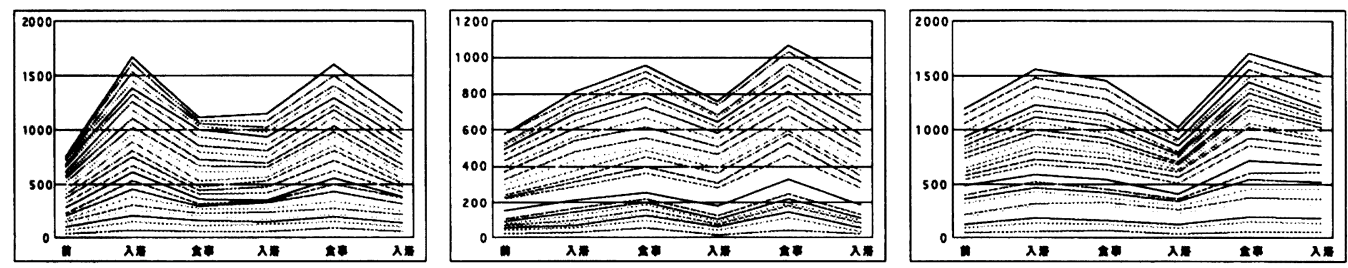


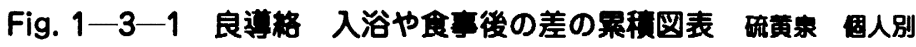
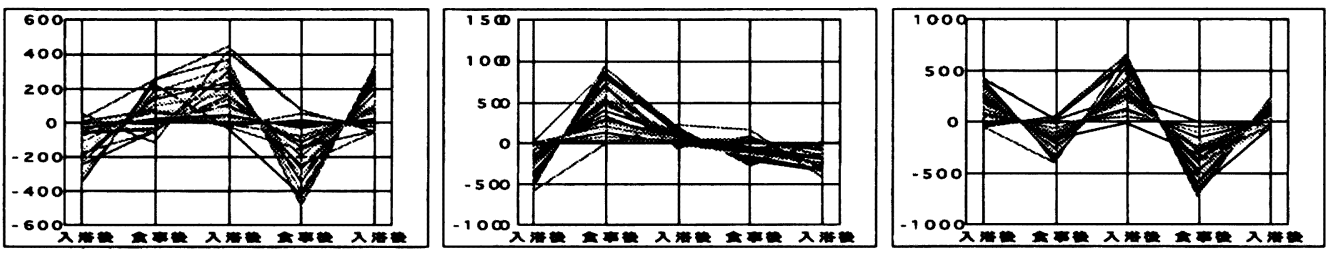

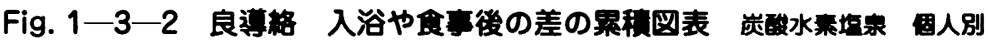
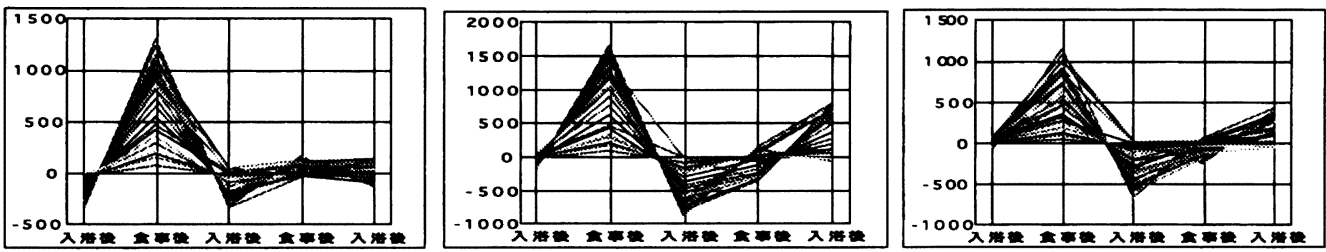


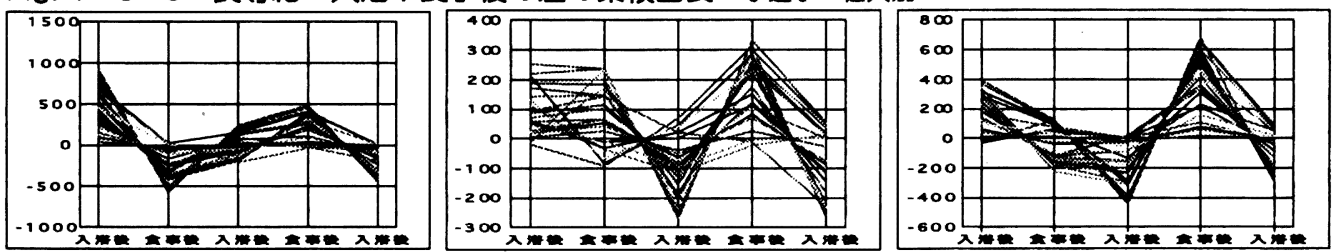

良導絡チャートの一日における最初のパ ターンは以後のパターンとほぼ同じょうで あった。しかし日内変動が認められ、一般に 朝低下し、以後次第に増加する傾向があった。 れらは被験者者によってすべて違っていて一 様ではなかった。

良導絡の変動は皮虎湿度と相関せず、また 更に食事や入浴によって影響を受けたが、そ 体インピーダンスとも無関係の動きを示した。

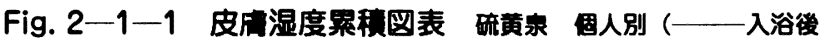
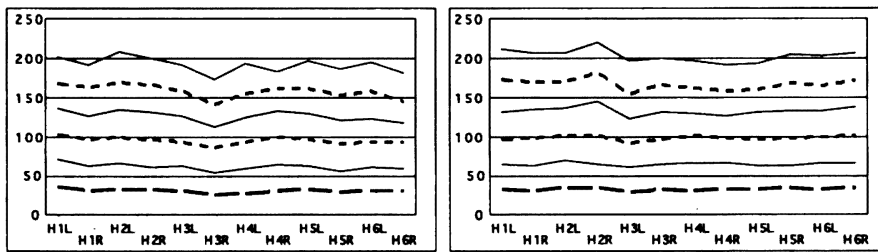

食後 - - - 初期宜)

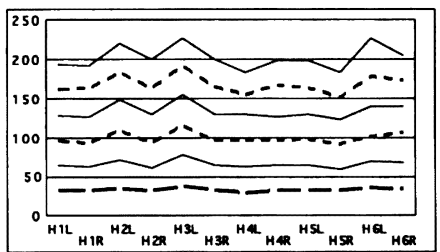

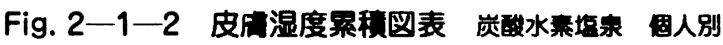
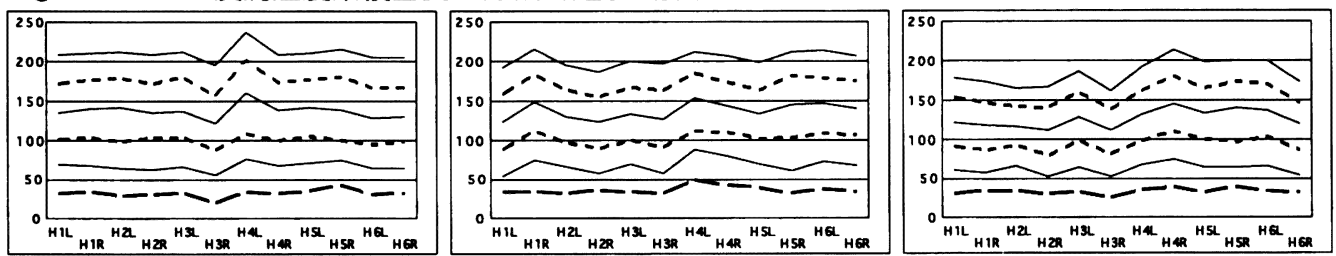

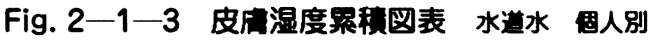
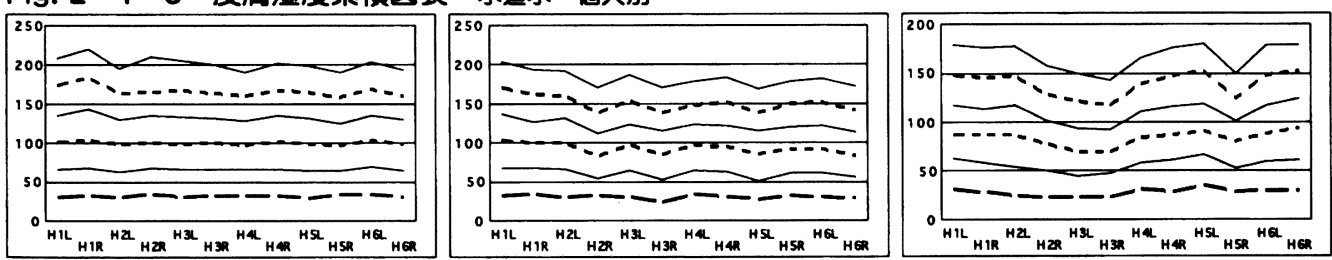


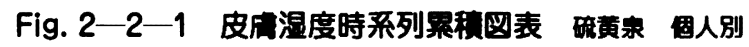
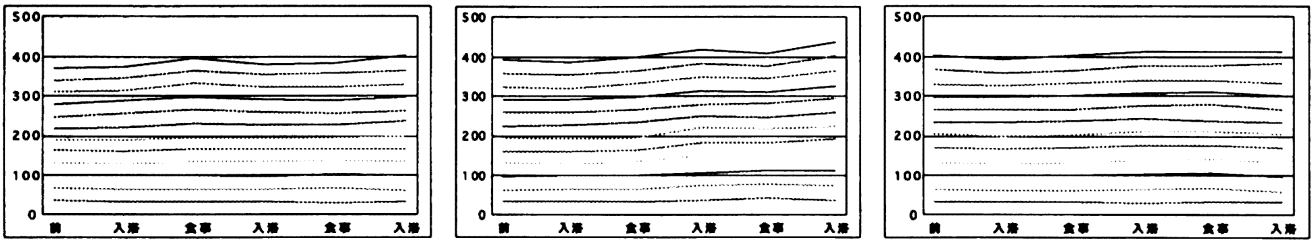

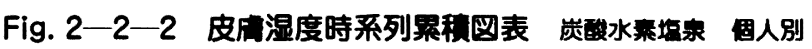
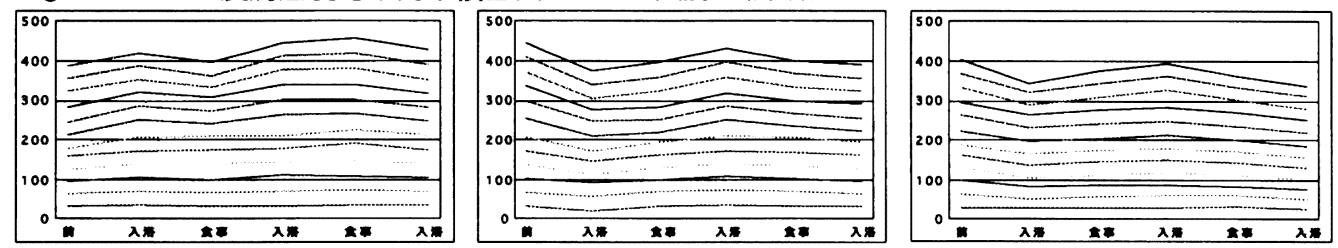

Fig. 2-2-3 皮夙湿度時系列累䅡图表 水道水 㑭人別
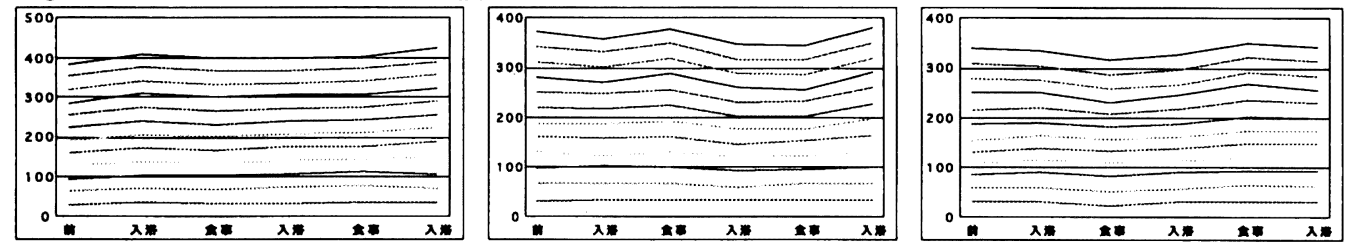

Fig. 2-3-1 皮同湿度 入浴也食事後の差の累积図表 硫黄㲾 個人別



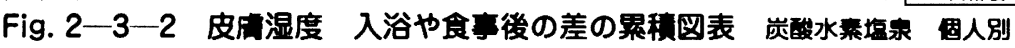
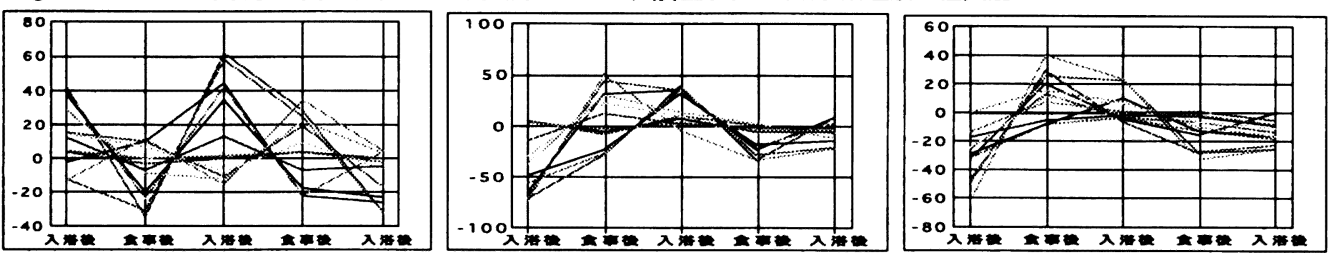

Fig. 2-3-3 皮栭湿度 入浴や食事後の差の累䅡図表 水道水 㑭人別
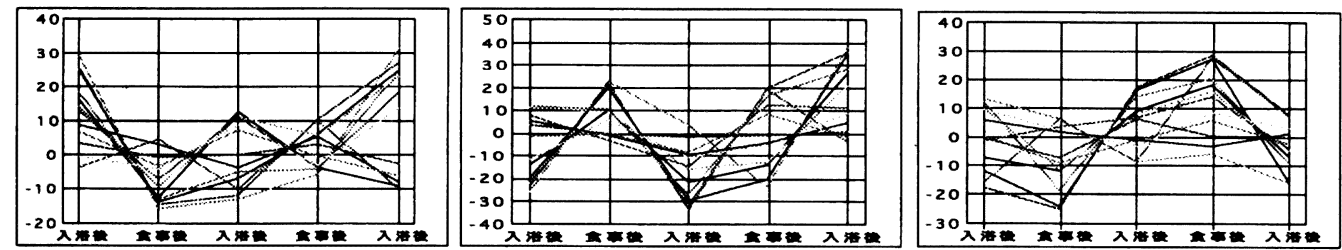
Fig. 3-1 体インピーダンス（各群 3名ずつ）


Fig. 3-2 体インピーダンス 入浴や食常後の差（各群 3名ずつ）
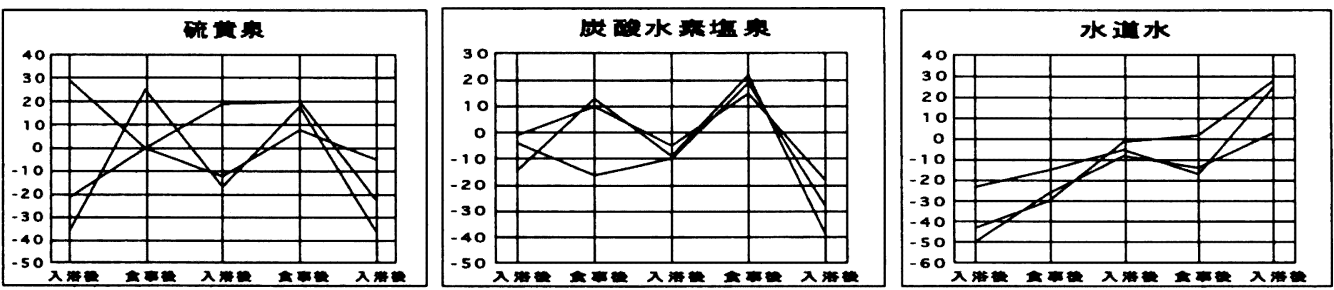

浴水の平均 $\mathrm{ORP}$ は水道水 $527 \mathrm{mV}$ 、炭酸水素 の入浴後の尿のORPはいずれも朝高く時間と 塩泉 $407 \mathrm{mV}$ 、硫黄泉 $145 \mathrm{mV}$ であった。三種類 ともに次第に低下する傾向を示した。

Fig. 4-1 尿の酸化通元正位（mV）（各群 3名ずつ）
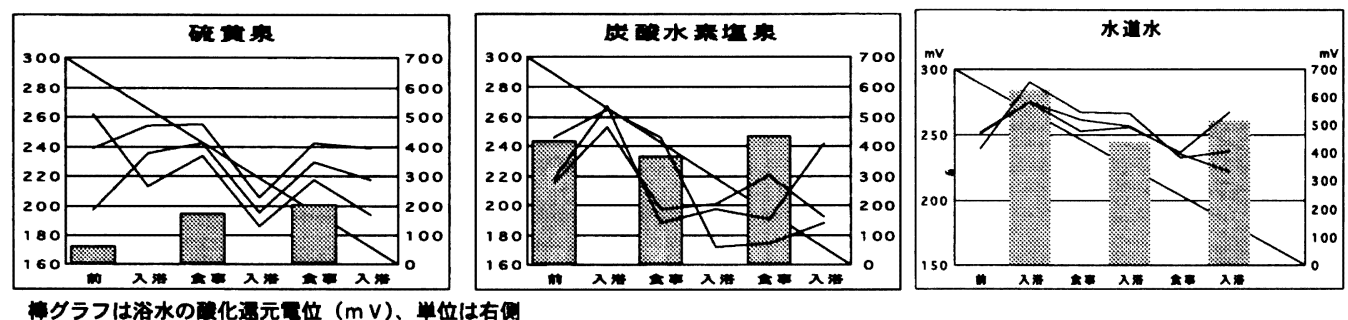

入浴や食事毎の尿 ORPの変化については、 その直前の值との差を取ると、表 4 に示され 加、硫黄泉浴では減少し、炭酸水素塩泉では るがごとく、明らかに入浴後水道水浴では増 それらの中間の值を示した。

Fig. 4-2 尿の酸化通元の位（mV） 入浴や食毫後の差（各群 3名ずつ）

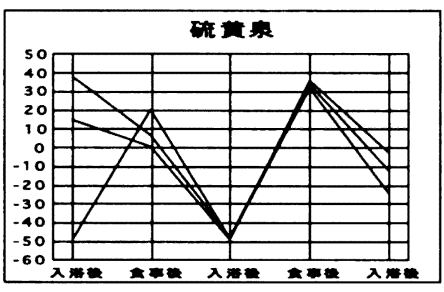

また初回を除く入浴後の尿 ORPの平均は、 水道水 $257 \mathrm{mV}$ 、炭酸水素塩泉 $220 \mathrm{mV}$ 、硫黄泉 $216 \mathrm{mV}$ であった。

食事や入浴後の良導絡と尿のORP変動を図 に示す。(Fig.1-3-1～3、Fig.4-2) 硫黄 泉浴と水道水浴では良導絡の変動は相反する 動きを示すことが多く、炭酸水素塩泉ではそ
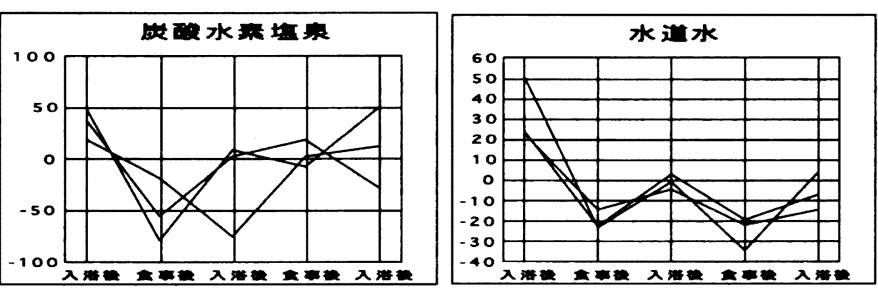

れらの中間の動きを示した。また良導絡およ び尿のORPは共に相反する変動を示すことが 多かった。

白血球分画の好中球リンパ球比は 6 時に比 し 12 時及び 16 時には検査したすべてで有意 に増加した。しかし浴水の違いによる差は明 らかではなかった。 
表 5 好中球リンパ球比に関する分散分析表

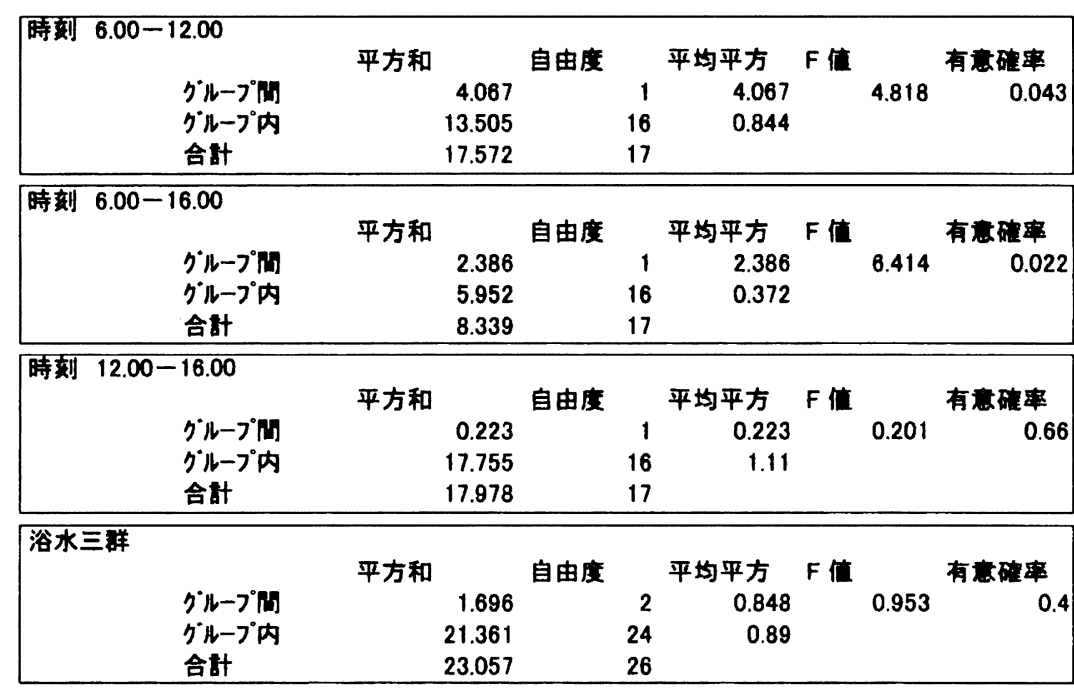

Fig. 5-1 好中球リンパ球比 測定時刻による差 個人值の累程図表

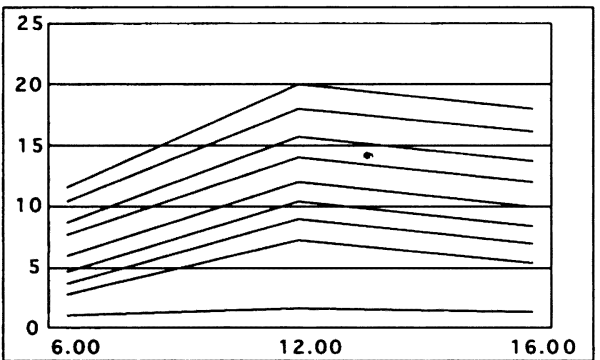

6.00 対 12.00 、及び 6.00 対 16.00 の二群の差の梌定值 $p=0.043 、 0.02212 .00$ 対 16.00 の二群には有意差なし

試験当日の各測定時刻における気温、湿度 及び気圧の変動は小さく、試験結果には影響

\section{表 6 試駼時刻における気温、湿度及び気圧}

\begin{tabular}{|c|c|c|c|c|c|c|}
\hline & 時刻 & 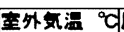 & 瘦外泟度 \% &  & 旺内湿度 96 & 気压 $\mathrm{hPa}$ \\
\hline 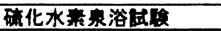 & 6.00 & 4.8 & 62 & 10.1 & 39 & 1003.6 \\
\hline \multirow[t]{5}{*}{$2003 / 03 / 16$} & 8.00 & 5.6 & 54 & 11.1 & 39 & 1003.4 \\
\hline & 10.00 & 7.1 & 55 & 12.1 & 38 & 1003.4 \\
\hline & 12.00 & 8 & 52 & 12.7 & 38 & 1002.1 \\
\hline & 14.00 & 8.6 & 45 & 13.1 & 38 & 1000.4 \\
\hline & 16.00 & 8.3 & 46 & \begin{tabular}{l|l|}
16.9 \\
\end{tabular} & 33 & 1000.2 \\
\hline 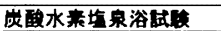 & 6.00 & 2.6 & 49 & 8.9 & 40 & 1007.6 \\
\hline \multirow{5}{*}{$2003 / 03 / 23$} & 8.00 & 3.7 & 44 & 9 & 40 & 1007.5 \\
\hline & 10.00 & 6.7 & 35 & 9.8 & 38 & 1006.8 \\
\hline & 12.00 & 8.4 & 30 & 9.9 & 39 & 1005.9 \\
\hline & 14.00 & 8.9 & 33 & 10.3 & 40 & 1004.8 \\
\hline & 16.00 & 9.1 & 27 & 10.8 & 42 & 1004.8 \\
\hline 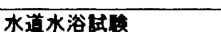 & 6.00 & 6.4 & 38 & 102 & 42 & 9955 \\
\hline \multirow[t]{5}{*}{$2003 / 03 / 30$} & 8.00 & 7.5 & 37 & 10.9 & 41 & 995.9 \\
\hline & 10.00 & 8.9 & 33 & \begin{tabular}{ll|}
11.3 \\
\end{tabular} & 40 & 996.6 \\
\hline & 12.00 & 9.7 & 32 & 11.4 & 41 & 996.7 \\
\hline & 14.00 & 10.5 & 27 & 11.8 & 41 & 995.6 \\
\hline & 16.00 & 10.3 & 27 & 11.9 & 41 & 995.6 \\
\hline
\end{tabular}




\section{【考 察】}

良導絡は交感神経切断後反応が消失するこ と、夏に高く、冬低いことなどから交感神経 と関係が深く、汗腺の活動が関与するであろ うと言われてきた1) 2)。今回の結果から良導 絡は好中球りンパ球比と同じように朝低く、 午後にかけて高くなる傾向があり、

その点では交感神経緊張度と関係する3）4) ようであった。

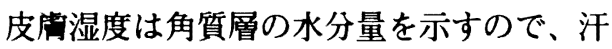
分泌と関係すると思われるが、良導絡とは関 係が見られなかった。これは良導絡や EDR (Electric Dermal Activity) あるいはGSR (Galvanic Skin Responce) 等と言われている 皮虚電気現象が汗腺活動に関係しても汗の量 とは無関係である5６）7）と従来言われてきた ことと一致した。

良導絡の測定は入浴後 2 時間を経てからで あり、当日の湿度はいずれも50\%以下で大き な変動はなかったので、浴水で皮膚が濡れる 影響や大気の湿度の影響はないものと考元ら れた。また気温や気圧も良導絡に影響すると 言われているが、当日の試験時刻内のそれら の変動は小さく無視できると考えられた。統 計的に測定部位毎の良導絡の大きさに男女別 の違いは見られるものの、各部位の興、抑の 頻度には全く差が見られない8)ことから、そ の変動に男女差はないものと思われ、試験に 際しての性別による区別は行わなかった。

$50 \mathrm{MHz}$ の交流電圧負荷によって皮虞の直流 に対するバリアは消失して電流が流れ、表皮 を含めた生体の全インピーダンスが得られる。 今回の結果は今まで言われてきたように1)生 体内部の電気インピーダンスが良導絡と無関 係であることを示した。これは良導絡が表皮 の現象であることを意味するものと考えられ た。

今回入浴により尿のORPが直ちに影響を受 けた。(Fig.4-1)これは硫黄泉の場合還元性 の強い硫化水素が、また水道水では酸化性の 強い過塩素酸が皮膚から吸収され尿に排泄さ れることを意味し、炭酸水素塩泉では酸化還
元的性質を示さない物質に対する入浴反応を 示すものと思われた。

食物が尿の ORPに与える影響については、 $\mathrm{VC} 2 \mathrm{~g}$ の㠌取では尿の ORP に影響が見られ ず、4gの摄取で始めて影響が見られ、8gの連 続摄取で血清尿酸に影響するとの報告等9) 10) があることから無視できると考えている。

尿のORPは多くの場合良導絡と逆相関する 変動を示した。(Fig.1-3、Fig.4-2) 浴水の ORP が高ければ浴後直ちに尿の ORP が高く なり、その際良導絡值が減少し、反対に浴水 の ORPが低ければ尿の ORPが低くなり、良 導絡値は增加することが多かった。尿のORP は体液の ORP を反映すると考えられるので、 それは良導絡が体液の個々の成分によってよ りも、体液の電気的な性質によって影響され ることを示しているように思われた。

\section{【結 語】}

入浴による良導絡への影響を硫黄泉、炭酸 水素塩泉及び水道水浴を用い、体インピーダ ンス、皮虐湿度: 尿の酸化還元電位及び好中 球リンハ球比との関係等から調べた。

その結果次の成績が得られた。

1 :良導絡は朝低下し、以後次第に高くなる傾 向が認められた。また好中球りンパ球比は 朝低くその後高くなり、推計学的に有意で あった。これは上記現象が交感神経の影響 によることを示すものと考えられた。しか し浴水の違いによる好中球リンハ球比に有 意差はなかった。

2：良導絡は体インピーダンスや皮膚湿度と は関係が見られなかった。これは良導絡が 表皮の現象であることを示すものと思われ た。

3 : 入浴の際浴水の酸化還元電位が低ければ 良導絡は増加し、酸化還元電位が高ければ 低下する傾向が認められた。これは体液の 電気的性質が良導絡に影響することを示す ものと思われた。

\section{【文 献】}

1 ）中谷義雄：(1966)、良導絡医学概論、分 
極と交感神経との関係、良導絡研究所、東 京、 $12-13$

2 ) 平井清子、久下浩史、河内明、他: (2001)、 胸腔下胸部交換神経節切除術による良導 点電流量の変化 (第2 報) - 代表測定点に おける手術前・後の変化 - . 日本良導絡自 律神経学会雑誌；47（1）13-17

3 ）安保徹：(1997)、気圧と疾患一虫垂炎 - . 治 療 $79(10), 145-150$

4 ) Sancier KM: (2003), Electrodermal measurements for monitoring the effects of a quigong workshop, J Altern Med, 9(2), $235-241$

5 ) Wolfram Boucsein: (1992), Electro- dermal Activity, 1.3.4 Specific physiological mechanisms underlying electrodermal activity, Plenum Press New York and London, p30-39
6 ）新美良純、白藤美隆：(1969)、皮虐電気 反射基礎と応用第「章皮虐抵抗水準と皮 虚抵抗反射の諸性質と末梢ならびに中枢 発現機序、医困薬出版株式会社、東京、 p12 - 33

7 ) 中谷義雄：(1984）, 良導絡自律神経調整 療法，第4版皮虐通電抵抗について良導絡 事業本部，東京、 $\mathrm{p} 8-11$

8 ）中谷義雄：(1973），良導絡自律神経調整 療法，第2版男女別と良導絡興奮性につい て良導絡事業本部，東京、p127-128

9 ) Stein HD, Hasan A, Fox IH : (1976), Ascorbic acid - induced uricosuria- A consequence of megavitamin therapy. Ann Int Med: 84, 385-388

10）高橋伸彦、大塚吉則：(2004), 温泉入浴 が尿酸排泄に及ぼす影響について、日温 気物医雑誌、67（2）、79-86 